\title{
Reply to Anatol Lieven
}

\author{
Michael Mann ${ }^{1}$
}

Published online: 23 January 2016

(C) Springer Science+Business Media New York 2016

I thank Anatol Lieven for the kind words expressed at the beginning of his critique and for his conclusion that I am a brilliant political economist. He reasonably enough notes some of the things I neglect, like India and Africa, and the politics of personal identity, to which I can only reply in pragmatic terms - is not the book long enough without them? He says very little about either economic or military power, which is at least half the book. He focuses overwhelmingly on the intersection of ideological and political power, especially on nationalism and what he calls "political culture." So I too will focus on this terrain. We obviously disagree on some issues. However, some of his substantive criticisms are mixed in with misunderstandings of my arguments, often due to the fact that he has not apparently read - or not read carefully enough - the second and third volumes of my Sources of Social Power.

This is especially true of nationalism, which he accuses me of neglecting in my previous volumes as well as this one. This is untrue. My second volume, on the long nineteenth century, has the subtitle "The Rise of Classes and Nation-States" and its central argument is that the two emerged entwined, mutually influencing one another. For example, I argue that the resolution or repression of class conflict went beyond the local or sector level and served to increase the salience of the nation-state in peoples' everyday lives. Despite what he says, I also discuss the rise of mass national education and mass national armies. I stress that the origins of modern welfare states lay in veterans' benefits, specifically discussing the Bismarckian programs in Germany, although in the case of France and the USA, I trace this practice further back, well before Bismarck. Clearly, national identities intensified in the nineteenth century, although I stand by my argument that "a sense of nationhood did diffuse but rarely dominated people's consciousness." Here, we clearly disagree. I would also stick by my statement that nineteenth century states did a lot less than twentieth century states, or that aggressive nationalism grew much more in the twentieth century.

But my discussion of nationalism and national self-identification is more nuanced than a simple "rise and rise" story. I try to identify the precise social location of emergent nationalism, seeing its nineteenth century heartland as the middle class who worked in the state sector. Outside this sector, I do not find much support for aggressive nationalism. For example I say,

Michael Mann

mmann@soc.ucla.edu 
following Porter (2005), that the mass of the British population showed little interest in the British Empire and did not much identify with it. In the second and third volumes, I attack the notion which Lieven and many others advance that aggressive nationalism was responsible for World War I. I see this as much less important in the causes of the war than traditional elites making complex geopolitical calculations and mistakes mixed in with aggressive or aggrieved personal emotions which speeded the path to war. I liken them to little boys fighting in the schoolyard. There was a rally around the flag surging in the early months of the war, but it did not last. I conclude an analysis of why the soldiers fought by saying that the predominant reason was that they were used to loyally obeying the demands of their social superiors, as had their predecessors over many centuries. These were class societies whose political and military structures were regarded as normal, indeed usually legitimate. This remains true today. I do not deny the widespread presence of what Billig (1995) called "banal nationalism" which could be evoked and amplified into aggressive nationalism in wartime. But my overall argument, stated most clearly in Mann (2013), is that nationalism did not generate the war, rather war intensified nationalism. I assume we disagree about this. We are probably closer together on World War II, which as I say in that article was certainly precipitated by the strength among German and Japanese elites, with much popular backing, of extreme nationalist militarisms. But other countries had little aggressive nationalism.

Lieven's criticism that I neglect American political culture is also misplaced. In this category, he stresses "American exceptionalism." Though all countries are different, I reject exceptionalism as it has been traditionally argued. I say in both volumes 3 and 4 that the principle American exceptionalism has been racism within America. The other great powers had racism abroad in their empires, though immigration is now finally bringing racism home to them as well. And despite what he says, I emphasize that the federal political system had distinctive consequences in conjunction with racism, since it entrenched the political power of the reactionary south and continues to do so. This is an important part of my lengthy attempt to solve the puzzle of why so many ordinary contemporary Americans are conservatives. I find many causes but one of them is the federal political system.

From World War II, a second strand of exceptionalism emerged - the extraordinary power of the global American Empire, which I discuss at great length in volume 4. However, its imperialism and militarism did not have long and continuous historical roots. Until World War II, the USA was not a major military power and it was dragged into the war only when Japan attacked it. Roosevelt had been trying to manipulate a reluctant Congress and people into war for 2 years before this, without much success. Some elite strategists immediately began plotting for world domination after the war (as I detail) but the American people were oblivious of this. It took some years for Americans to embrace their power, and their attitude to American Empire remains ambivalent. We are the greatest country in the world, yes. But do not mention the word empire and please do not produce many casualties.

In foreign policy, elites still rule and are routinely obeyed. They can easily portray Saddam Hussein and others as evil men threatening the USA. Most people accepted this, but the combination of casualties and the absence of weapons of mass destruction evaporated their enthusiasm for war. Today, though Republican elites call for further military interventions, these would not be popular.

I also argue that a third strand of exceptionalism has emerged in recent years: the extraordinarily high level of economic inequality, though I qualify this by observing that the other Anglophone countries are travelling the same path, if less far. So my American "exceptionalisms" are few, specific, and involve different time frames. 
I reject notions of enduring American ideologies like a generalized American exceptionalism and an idealized American Creed. Lieven himself (2004) has previously replaced the idealized American Creed with its exact ideological opposite, "a wounded and vengeful nationalism." He seems to still adhere to this formulation. But reality is not so stark as any of these formulations. American ideologies have always been multiple and competitive, with strong regional and class differences, and many changes through time. Thus I reject, not neglect, many of the ideas advanced by his list of famous American writers, although I should add that my practice in all my volumes has been to state my own arguments rather than demolish those of others. In volume 3, I do refer to Mead's typology of foreign policy. I also note ambivalence in the myth of the USA as the "shining city on the hill." Does our shining city mean we should merely set an ideal example for the world to follow, or does it mean we should intervene abroad to impose the ideal? There has been something of a historical shift from the former toward the latter, but ambivalence remains and at present constrains the Obama administration.

The major point of difference between us in the realm of ideological power is that Lieven allows ideologies and especially "ideological nationalism" a greater coherence and a greater causal power than I do, whether in the causes of World War I or in what he calls the contemporary "paralysis" of the American political system. He argues that conservatives have developed an attachment to the US Constitution "which verges on religious fanaticism" and that this is fueled by a "growing sense of white conservative embattlement." Of course there are strong ideological currents in American politics, and Bible Belt conservatism and neoliberalism are good examples of this. But is the country as a whole driven by ideologies?

I accept that ideological differences between conservative and liberal elites have been recently widening, and I say so myself in volume 4. But actually both conservatives and liberals are attached to the constitution, each to different parts of it, and they are uncomfortable with other parts. Conservatives would like to see blurred the separation of religion and the state, and they are not keen on much of the Bill of Rights. I also find his statements about the white working and middle classes far too sweeping. In volume 4, I give a detailed 10-page analysis of who does and does not embrace conservatism. There is still a class difference in voting, with the less privileged more likely to vote Democrat and professionals and executives more likely to vote Republican. Because of massive urban differences, whites in the cities vote mostly Democrat, while whites in the rural areas vote mostly Republican, especially in the Bible Belt. Rural folk are actually more concerned with moral than economic issues, the reverse of the cities. Across the country as a whole, most women vote Democrat, while most men vote Republican. In opinion polls, the vast majority of Americans voice views that are conservative on some issues and liberal on others. This is a more complex and less dramatic affair than Lieven suggests.

I find the notion of paralysis similarly exaggerated, though he is in good company here. The Supreme Court continues to make laws as it pleases and the political parties do produce agreed budgets after much posturing. Lieven puzzingly says that paralysis especially affects economic policy, yet Obama got through a bigger stimulus program than any European country, and the federal government offers bigger subsidies to corporations than do other governments - which both contradict America's rhetorical neoliberalism. Obamacare was introduced despite ferocious Republican opposition and it flourishes. The Republicans will probably downplay their hostility to it in the run-up to the next election. Of course, if the President is of one party and Congress is of the other, there is a tendency toward gridlock, but this is hardly a new feature of American politics and it means that the conservatism he emphasizes does not rule. 
In other words, ideological power plays a lesser role in America than Lieven suggests. Politics for him is "political culture" of an ideological hue, while he ignores pragmatic wheeler-dealing. Yet in reality, all political factions continually strategize on their programs and how to present them. They defer to spin doctors, people who lack ideology but have a track record of winning elections. They also defer to their big money backers so that they can mount the well-funded campaigns which are the backbone and bane of American politics. In this process, ideologies are weakened except when talking to particular constituencies like the Bible Belt or the Republican Party faithful. The Republican oscillation problem is well known. Candidates in the primaries must spout extreme conservatism, but in the general election, they must position themselves in the center. A little ideology is mixed with a great deal of material calculation, as I try to show in my chapter on current American politics. In fact, I argue that the Republicans are more skillful in their pragmatism than their Democrat counterparts.

Lieven makes a few comments about my general model. He suggests that kinship should be a fifth source of social power. The case for this would be much stronger in primitive societies. Today, kinship is more micro than macro. It does not bind societies together. Some nationalisms do have a myth of common kinship (though obviously not the USA) but that is hardly their cement. I am more tempted by the notion that in modern societies (and only there), science/technology has become a fifth power source (see Mann, forthcoming). He mentions the criticism of my model that political power differs from the others because it is merely the product of the other three. But so is ideology, which is an attempt to deal with the economic, military, and political crises facing human beings. In Durkeimian terms, both political and ideological institutions have emergent power properties. Whatever the nature of their creation, once in play, they wield significant powers. The main political resource is law-setting and enforcing.

His main criticism at the level of theory is that I am indifferent to political culture which he claims binds together the four elements of my IEMP model (i.e., ideological, economic, political, and military power). I disagree. None of the four has more of a role in binding them all together. The significance of each varies between time and place. Indeed, I reject the notion that political culture in his highly ideological sense dominates political power relations except in unusual situations. Fascism, socialism, the Bible Belt, yes; big business politics and Washington, no. Political power is normally the art of the possible, though in crises, this may be swept away by the rhetoric of ideologists. If I am indeed a brilliant political economist, this is because I do not treat the economy as a self-contained system but as a set of institutions in continuous interaction and mutual influence with ideological, military, and political power institutions.

\section{References}

Billig, M. (1995). Banal nationalism. London: Sage.

Lieven, A. (2004). America right or wrong: an anatomy of american nationalism. Oxford: Oxford University Press.

Mann, M. (2013). The role of nationalism in the two world wars”. In J. Hall \& S. Malesevic (Eds.), Nationalism and war. Cambridge: Cambridge University Press.

Mann, M. forthcoming "Response to Critics" in John Hall \& Ralph Schroeder (eds.), Global powers: Mann's anatomy of the $20^{\text {th }}$ century and beyond. Oxford: Oxford University Press.

Porter, B. (2005). The absent-minded imperialists: what the British really thought about empire. Oxford: Oxford University Press. 